Check for updates

Cite this: RSC Adv., 2018, 8, 1569

Received 22nd November 2017 Accepted 21st December 2017

DOI: $10.1039 / \mathrm{c} 7 \mathrm{ra} 12667 \mathrm{k}$

rsc.li/rsc-advances

\section{Vertical liquid crystal orientation of phytochemical-based oryzanol modified polystyrene}

\begin{abstract}
Taehyung Kim, Changha Ju and Hyo Kang (D) *
Using plant-derived oryzanol, we synthesized a series of phytochemical-based oryzanol-modified polystyrenes (PORZ\#, \# = 20, 40,60, 80 , or 100 , where \# is the mole fraction of the oryzanol moiety) using polymer modification reactions in order to investigate their liquid crystal (LC) orientation behaviors. Generally, an LC cell made from polymer films with a higher mole fraction of the oryzanol side group showed vertical LC orientation behavior. The vertical orientation behavior was strongly correlated with the surface energy of these polymer films. For instance, the vertical orientation was observed when the polymer's surface energy, which is influenced by the nonpolar and long carbon groups, was less than about $40.42 \mathrm{~mJ} \mathrm{~m}^{-2}$. Good electro-optical properties, such as the aligning stabilities at $250{ }^{\circ} \mathrm{C}$ and ultraviolet (UV) irradiation of $20 \mathrm{~J} \mathrm{~cm}^{-2}$, the voltage holding ratio, and the residual DC voltage (R-DC), were observed for the LC cells fabricated using PORZ100 as an eco-friendly LC orientation layer.
\end{abstract}

\section{Introduction}

The orientation behavior of liquid crystal (LC) molecules has been intensively studied due to interest in scientific and technical applications in displays, such as both flexible and rigid displays. ${ }^{1-6}$ Polyimide derivatives are most commonly used as traditional LC orientation layers through the rubbing process, because they provide very stable and reliable LC orientation. ${ }^{7-16}$ Polyimide derivatives containing hydrophobic long-alkyl side groups such as n-octadecyl groups and (n-decyloxy)biphenyloxy side groups have been developed as vertical LC orientation layers. ${ }^{17-20}$ Baking processes using high processing temperatures over $200{ }^{\circ} \mathrm{C}$ are widely employed in order to produce conventional polyimide orientation layers. However, the baking temperature is too high to be practical for manufacturing flexible plastic devices. Therefore, long-alkyl-chain-modified polystyrene (PS) derivatives, which are comb-like polymers, have been synthesized as an alternative to polyimide derivatives to produce vertical LC orientation layers. For instance, LC devices fabricated with polymer films of $n$-alkylthiomethyl- and $n$ alkylsulfonylmethyl-modified polystyrenes with long alkyl chains (number of alkylcarbons $>8$ ) show vertical LC orientation properties. $^{21}$ The LC devices made using the 4alkylphenoxymethyl-substituted polystyrenes exhibit vertical LC orientation behaviors even at a high rubbing density, regardless of the length of the alkyl side chains. ${ }^{22}$

Department of Chemical Engineering, Dong-A University, 37 Nakdong-Daero 550beon-gil 37, Saha-gu, Busan 604-714, Korea. E-mail: hkang@dau.ac.kr; Fax: +82 51200 7728; Tel: +8251200 7720
Recently, chemical materials extracted from natural sources have been the focus of increased scientific and technical interest. Chemical substances extracted from natural products such as rosemary, thyme, and wheat often contain phenolic compounds such as tocopherol, genistein, lignan, etc. ${ }^{23}$ Phenolic compounds obtained from renewable products have been known to have antioxidant and antimicrobial properties. $^{\text {24-26 }}$ Moreover, the hydroxy group in the phenolic compounds can act as a nucleophile that can modify various inorganic and/or organic materials in order to control the physico-chemical properties of the target materials. ${ }^{27}$ For example, Y. Tsuda et al. suggested that surface properties such as the wetting behavior of the modified film can be controlled by attaching phenolic compounds. ${ }^{28}$ Oryzanol is one of the phenolic substances extracted from rice bran oil essence and the esterified product of triterpene alcohol and ferulic acid. Because oryzanol has a sterol moiety in its chemical structure, it can provide oxidation protection..$^{29,30}$ Especially, $\gamma$-oryzanol can decrease the absorption of low density lipoprotein (LDL), one type of cholesterol which is known to be detrimental to blood vessels, and can be used to protect against skin damage from UV rays. ${ }^{31,32}$ In addition, $\gamma$-oryzanol can reportedly reduce menopausal symptoms in women by increasing endocrine secretion, as previously studied by other research groups. ${ }^{33,34}$

In this study, phytochemical-based oryzanol modified polystyrenes (PORZ\#) were synthesized using plant-derived oryzanol in order to produce a vertical LC orientation layer and to examine the effect of the molar ratio of the side group chemistry on LC orientation. The optical and electrical properties of the LC cells made from the biorenewable polymer films are also included. 


\section{Experimental}

\subsection{Materials}

4-Chloromethylstyrene (CMS), $\gamma$-oryzanol, and potassium carbonate were purchased from Aldrich Chemical Co. and a nematic LC, MLC-6608 $\left(n_{\mathrm{e}}=1.5586, n_{\mathrm{o}}=1.4756\right.$, and $\Delta \varepsilon=$ -4.2 , where $n_{\mathrm{e}}, n_{\mathrm{o}}$, and $\Delta \varepsilon$ represent extraordinary refractive indexes, ordinary refractive indexes, and dielectric anisotropy, respectively), was purchased from Merck Co. $N, N^{\prime}$-Dimethylacetamide (DMAc) and methanol were dried over molecular sieves (4 A). Tetrahydrofuran (THF) was dried by refluxing with benzophenone and sodium followed by distillation. 4-Chloromethylstyrene was purified by column chromatography on silica gel using hexane as an eluent to remove any impurities and inhibitors (tert-butylcatechol and nitroparaffin). Poly(4chlorometh-ylstyrene) (PCMS of $M_{\mathrm{n}}=28000$ and $M_{\mathrm{w}} / M_{\mathrm{n}}=$ 2.22) was synthesized through conventional free-radical polymerization of the 4-chloromethylstyrene using 2,2'-azoisobutyronitrile (AIBN) under a nitrogen atmosphere. AIBN (Junsei Chemical Co., Ltd.) was used as an initiator. The AIBN was purified by crystallization using methanol. All other reagents and solvents were used as received.

\subsection{Synthesis of oryzanol-modified polystyrene}

The following procedure was used to synthesize all of the oryzanol-modified polystyrenes, PORZ\#, where \# represent the mole percent $(\%)$ of the $\gamma$-oryzanol moiety in the side group. The synthesis of the oryzanol-modified polystyrene (PORZ100) is given as an example. A mixture of $\gamma$-oryzanol (5.93 g, $9.83 \mathrm{mmol}$, $150 \mathrm{~mol} \%$ compared with PCMS) and potassium carbonate (1.631 g, $11.81 \mathrm{mmol}$ ) in $N, N^{\prime}$-dimethylacetamide (DMAc, 30 $\mathrm{mL}$ ) was heated to $75^{\circ} \mathrm{C}$. A PCMS ( $\left.1 \mathrm{~g}, 6.56 \mathrm{mmol}\right)$ solution in DMAc $(20 \mathrm{~mL})$ was added to the mixture and then magnetically stirred at $70{ }^{\circ} \mathrm{C}$ for $24 \mathrm{~h}$ under a nitrogen atmosphere. The solution mixture was cooled to room temperature and then poured into methanol to obtain a white precipitate. The precipitate was further purified by several reprecipitations from DMAc solution into methanol and then washed with hot methanol to remove potassium carbonate and any remaining salts. The precipitate was obtained in yields above $80 \%$ after drying overnight in a vacuum. The degree of substitution of the chloromethyl to the oryzanyl methyl ether group was found to be almost $100 \%$ within experimental error. The ${ }^{1} \mathrm{H}$ NMR peaks for the PORZ100 are as follows:

PORZ100 ${ }^{1} \mathrm{H}$ NMR $\left(\mathrm{CDCl}_{3}\right): \delta=0.8-2.2(45 \mathrm{H}), 3.8-3.9(4 \mathrm{H})$, 4.8-5.0 (2H), 5.0-5.2 (1H), 6.2-6.3 (1H), 6.8-7.2 (7H), 7.5-7.6 (1H).

Other polystyrene derivatives containing oryzanol side groups were synthesized using the same procedure used for the preparation of PORZ100 except that differing amounts of $\gamma$ oryzanol were used in the substitution reaction. For example, PORZ80, PORZ60, PORZ40, and PORZ20 were prepared with $\gamma$ oryzanol of $3.14 \mathrm{~g}(5.21 \mathrm{mmol}), 2.36 \mathrm{~g}$ (3.92 mmol), $1.56 \mathrm{~g}$ (2.59 $\mathrm{mmol})$, and $0.78 \mathrm{~g}(1.30 \mathrm{mmol})$, respectively, using slight excess amounts of potassium carbonate (1.631 g, $11.81 \mathrm{mmol}$, 180 mol\% compared with PCMS).

\subsection{Film preparation and LC cell assembly}

Solutions of each variant of PORZ\# were prepared in tetrahydrofuran (1 wt\%). These solutions were filtered using a PTFE membrane with a pore size of $0.45 \mu \mathrm{m}$. Thin films of the polymers were prepared by spin-coating $(2000 \mathrm{rpm}, 60 \mathrm{~s})$ onto glass substrates. LC cells were fabricated by first applying the polymer film to glass slides. The LC cells were assembled by separating the films using spacers with a thickness of $4.25 \mu \mathrm{m}$. The cells were filled with nematic LC, MLC-6608. The manufactured LC cells were sealed with epoxy glue.

\subsection{Instrumentation}

The ${ }^{1} \mathrm{H}$ NMR measurements were carried out on a Bruker AVANCE spectrometer at $300 \mathrm{MHz}$. The gel permeation chromatography (GPC) was used to measure the number average molecular weight $\left(M_{\mathrm{n}}\right)$ and polydispersity index $\left(M_{\mathrm{w}} / M_{\mathrm{n}}\right)$ of the synthesized polymer with respect to polystyrene standards using tetrahydrofuran (THF) as the eluent and an UV detector. The optical transmittance of the polymer films on glass substrates was obtained using UV-Vis spectroscopy (Perkin Elmer Lamda 20 spectrometer). The contact angles of distilled water and methylene iodide on the polymer films were determined with a Kruss DSA10 contact angle analyzer equipped with drop shape analysis software. The surface energy value was calculated using the Owens-Wendt's equation:

$$
\gamma_{\mathrm{sl}}=\gamma_{\mathrm{s}}+\gamma_{1}-2\left(\gamma_{\mathrm{s}}^{\mathrm{d}} \gamma_{1}^{\mathrm{d}}\right)^{1 / 2}-2\left(\gamma_{\mathrm{s}}^{\mathrm{p}} \gamma_{1}^{\mathrm{p}}\right)^{1 / 2}
$$

where $\gamma_{1}$ is the surface energy of the liquid, $\gamma_{\mathrm{sl}}$ is the interfacial energy of the solid/liquid interface, $\gamma_{s}$ is the surface energy of the solid, $\gamma_{1}^{\mathrm{d}}$ and $\gamma_{\mathrm{P}}^{\mathrm{P}}$ are known for the test liquids, $\gamma_{\mathrm{s}}^{\mathrm{d}}$ and $\gamma_{\mathrm{s}}^{\mathrm{p}}$ can be calculated from the measured static contact angles. ${ }^{35}$ The polarized optical microscopy (POM) images of the LC cell were taken using an optical microscope (Nikon, ECLIPSE E600 POL) equipped with a polarizer and digital camera (Nikon, COOLPIX995). The voltage holding ratio (VHR) was measured using a VHR measurement system (Autronic-MELCHERS, VHRM 105). The pulse width, frame frequency, and data voltages were $64 \mu \mathrm{s}$, $60 \mathrm{~Hz}$, and $1.0 \mathrm{~V}$, respectively. The measurement temperatures were 25 and $60{ }^{\circ} \mathrm{C}$. The residual DC voltage (R-DC) value was evaluated using a capacitance-voltage $(C-V)$ hysteresis method, which is used by Nissan Chemical Industries, Ltd.

\section{Result and discussion}

Fig. 1 shows the synthetic routes to the phytochemical-based oryzanol-modified polystyrenes (PORZ100) and copolymers (PORZ80, PORZ60, PORZ40, and PORZ20, where \# is the mole percent (\%) of $\gamma$-oryzanol side groups in the polymers). The different degrees (\%) of substitution in the copolymers were obtained by changing the amounts of $\gamma$-oryzanol at interval of $20 \mathrm{~mol} \%$ in the modification reaction. The rate of conversion from chloromethyl to oryzanyl methyl ether was almost $100 \%$, when $150 \mathrm{~mol} \%$ of $\gamma$-oryzanol was used at $75{ }^{\circ} \mathrm{C}$ for $24 \mathrm{~h}$, as determined by analysis of the respective proton peaks of the oryzanol-containing homopolymer (PORZ100). The chemical 


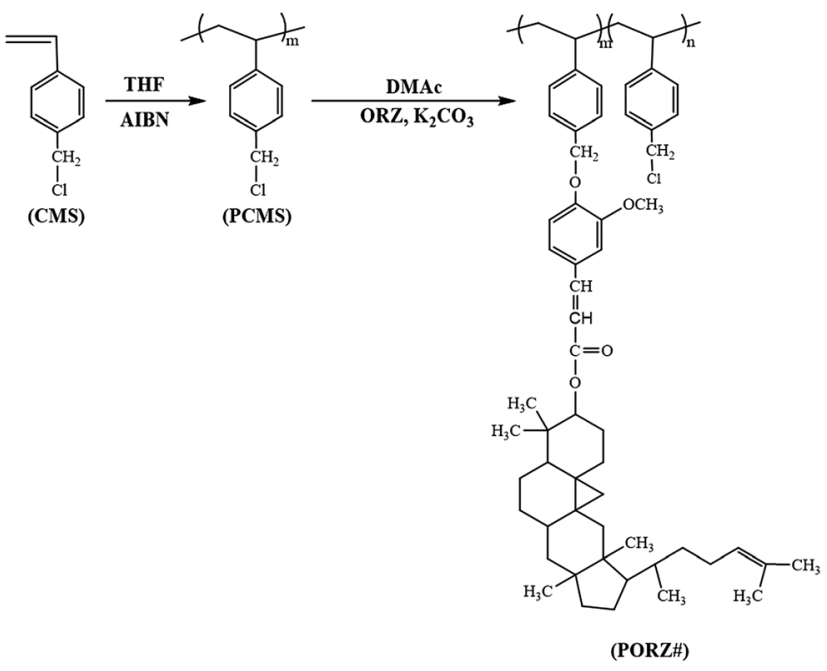

Fig. 1 Synthetic route to oryzanol modified polystyrene (PORZ\#).

compositions of the monomeric units in the synthesized polymers were confirmed by ${ }^{1} \mathrm{H}$ NMR spectra. The ${ }^{1} \mathrm{H}$ NMR spectrum of PORZ100 indicates the presence of protons from the styrene backbone ( $\delta=6.8-7.2 \mathrm{ppm})$. $(1 \mathrm{H}), 6.2-6.3(1 \mathrm{H}), 7.5-7.6$ $(1 \mathrm{H})$ indicate the inclusion of oryzanol moieties in the polymer. The oryzanol content could be calculated by comparing the integrated area under the proton peaks of the oryzanol $(\delta=5.0-$ 5.2 and 6.2-6.3 ppm) and chloromethyl side chains $(\delta=4.8-5.0$ $\mathrm{ppm})$. The calculated oryzanol contents of these polymers, including PORZ100, are shown in Table 1. Similar integrations and calculations were performed for PORZ80, PORZ60, PORZ40, and PORZ20 and were typically within $\pm 5 \%$ of the expected values from the synthesis. The average molecular weights $\left(M_{\mathrm{n}}\right)$ of the polymers synthesized from the polychloromethyl-styrene (PCMS, $M_{\mathrm{n}}=28000$ ) were always larger than 31000 indicating that polymer modification from PCMS to PORZ\# increased the average molecular weight $M_{\mathrm{n}}$, as expected (Table 1). These polymers are soluble in medium-polarity solvents with low boiling points, such as tetrahydrofuran (THF) and chloroform, and in aprotic polar solvents, such as $N, N^{\prime}$-dimethylformamide (DMF), $N, N^{\prime}$-dimethylacetamide (DMAc), and $N$-methyl-2pyrrolidone (NMP). The solubility of all polymer samples in

Table 1 Reaction conditions and results for the synthesis of the PORZ\#

\begin{tabular}{lllll}
\hline $\begin{array}{l}\text { Polymer } \\
\text { designation }\end{array}$ & $\begin{array}{l}\gamma \text {-Oryzanol } \\
(\mathrm{mol} \%)\end{array}$ & $\begin{array}{l}\text { Degree of } \\
\text { substitution }(\%)\end{array}$ & $M_{\mathrm{n}}{ }^{a}$ & $M_{\mathrm{w}} / M_{\mathrm{n}}{ }^{a}$ \\
\hline PORZ0 & - & - & 28000 & 2.22 \\
(or PCMS) & & & & \\
PORZ20 & 20 & 20 & 31000 & 2.55 \\
PORZ40 & 40 & 40 & 33000 & 2.59 \\
PORZ60 & 60 & 60 & 36000 & 2.41 \\
PORZ80 & 80 & 80 & 39000 & 2.73 \\
PORZ100 & 150 & 100 & 40000 & 2.55
\end{tabular}

${ }^{a}$ Obtained from GPC using tetrahydrofuran (THF) as solvent with respect to monodisperse polystyrene as standard. various solvents is good enough for the polymers to be used as thin film materials for electro-optical devices.

The thermal properties of these polymers were investigated using differential scanning calorimetry (DSC). All the polymers were amorphous as only one glass transition was observed from each DSC thermogram. As the mole fraction of the oryzanol side group in the polymers increased, the glass transition temperature $\left(T_{\mathrm{g}}\right)$ value increased from $145{ }^{\circ} \mathrm{C}$ for PORZ20 to $158{ }^{\circ} \mathrm{C}$ for PORZ100 (Fig. 2). Generally, the $T_{\mathrm{g}}$ value of polymers depends on the properties such as polarity, flexibility, and bulkiness of the side group. The $T_{\mathrm{g}}$ of the polymers has been reported to increase with increasing polarity of the side groups ${ }^{36}$ while the $T_{\mathrm{g}}$ of the polymers can increase or decrease with increasing bulkiness of the side group. For example, the $T_{\mathrm{g}}$ of the poly(vinylnaphthalene) with relatively bulky substituents, such as naphthalene, is higher than that of polystyrene. ${ }^{36}$ This means that the incorporation of a bulky side group, such as naphthalene, can increase the intermolecular interactions in the polymer. Likewise, in this study, the incorporation of a bulky side group such as oryzanol affects the intermolecular interactions of the polymer in the same way, which increases $T_{\mathrm{g}}{ }^{36}$

Quantitative analysis of the optical transmittance of PORZ\# films was performed using UV-Vis spectroscopy to investigate the polymer's suitability for coating applications (Fig. 3). The optical transmittance value of the PORZ\# film coated on a glass substrate is in range of 97.9 to $99.3 \%$ at $550 \mathrm{~nm}$, which is higher than that $(80.5 \%)$ of the commonly used polyimide film. The PORZ\# film also avoids a problem the polyimide film has with intrinsically yellowish coloration, ascribed to the diimide fragment conjugation when used as a LC orientation layer. The PORZ\# film's optical transmittance in the visible light region is definitively good enough for it to be used as an optical material in electro-optical devices such as displays.

Fig. 4 exhibits images of the LC cells made from PORZ100 films on glass substrates using the following weight percentages of PORZ100: 0.005, 0.01, 0.05, 0.1 and $1.0 \mathrm{wt} \%$. At first, as shown in Fig. 4(a)-(d), partial vertical orientation was observed in PORZ100 with a weight ratio of less than $0.1 \mathrm{wt} \%$. When the PORZ100 weight ratio is $1.0 \mathrm{wt} \%$, uniform vertical orientation was observed as shown in the image of the LC cell in Fig. 4(e).

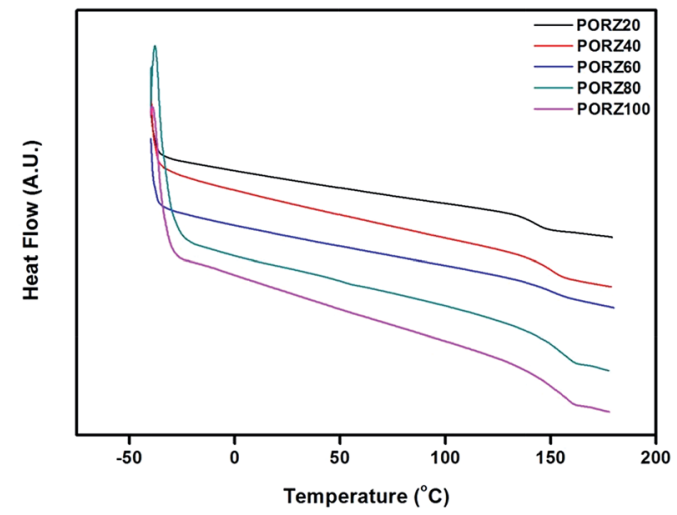

Fig. 2 DSC thermogram of oryzanol modified polystyrene (PORZ\#). 


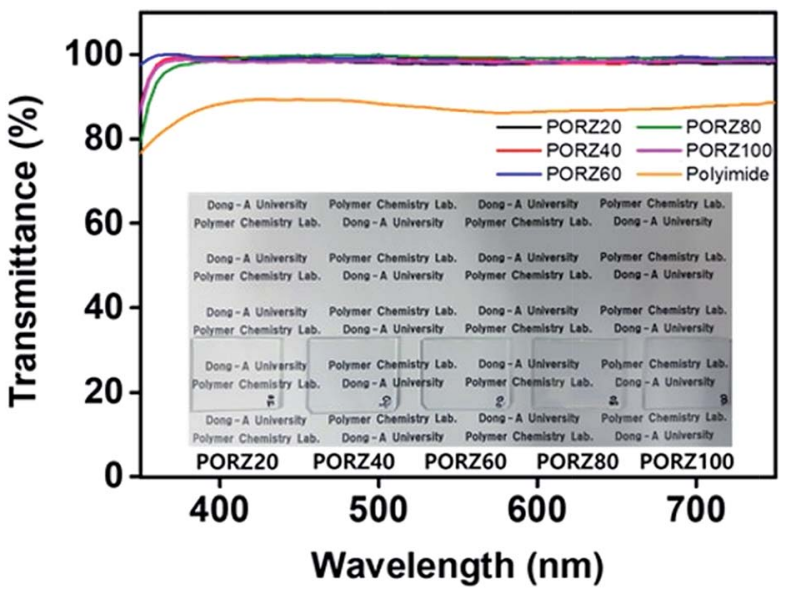

Fig. 3 Optical transmittance spectra of PORZ\# and polyimide orientation layers onto quartz substrates.

Therefore, a $1 \mathrm{wt} \%$ solution was chosen as the coating solution in order to fabricate LC cells made from PORZ\# films.

Fig. 5 shows the photographs of the LC cells fabricated using the homopolymer (PORZ100) and copolymers (PORZ\#, \# = 8020). At first, random planar LC orientation was observed for the LC cells made from the polychloromethylstyrene (PCMS or PORZ0) film (data not shown). The LC cells fabricated with the PORZ\# films having an oryzanol side group content of more than about $20 \mathrm{~mol} \%$ (PORZ20, PORZ40, PORZ60, PORZ80, and PORZ100) show vertical LC orientation behavior in the entire photographed area in the images of the LC cells.

All of the PORZ\# films were able to produce stable vertical LC orientation layers and vertical LC orientation was sustained for at least one year since we first made the LC cells from these polymers. Therefore, as the mole fraction of the oryzanol side groups increases, the vertical LC orientation in the LC cell increases. The LC orientation behavior of the LC cells fabricated with the PORZ\# films were examined with conoscopic polarized optical microscopy (POM) (Fig. 6). Random planar LC orientation was observed in the LC cells fabricated using the PCMS (or PORZ0) film. On the other hand, all of the PORZ\# films were able to produce stable vertical LC orientation layers as shown by the "Maltese cross" pattern of conoscopic POM image. Based on the results obtained for the LC orientation behavior, we observed a general trend that the polymers with a higher mole fraction of oryzanol side groups have a preference for vertical LC orientation. It is widely known that the high pretilt angles of LC molecules associated with the vertical orientation behavior are

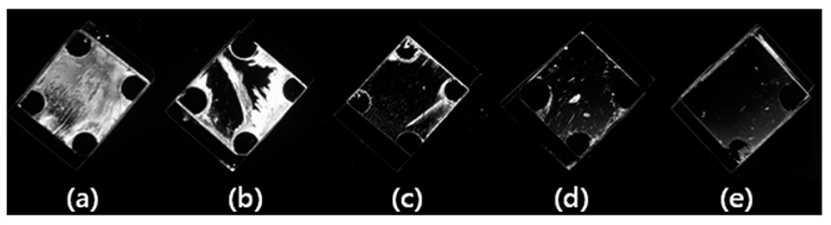

Fig. 4 Photograph images of the LC cells made from PORZ100 films under the following a weight ratio of the PORZ100; (a) 0.005, (b) 0.01, (c) 0.05 , (d) 0.1 and (e) $1.0 \mathrm{wt} \%$.

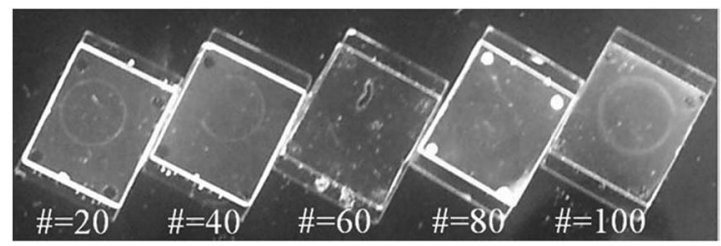

Fig. 5 Photograph images of the LC cells fabricated with PORZ\# films according to the molar content (\#) of $\gamma$-oryzanol moiety.

related to the low surface energy of the orientation layer surfaces and/or the steric repulsions between LC molecules and the orientation layers..$^{37,38}$

For example, polyimide derivatives containing the nonpolar and bulky groups such as pentylcyclohexylbenzene ${ }^{37}$ and $4-(n-$ octyloxy)phenyloxy ${ }^{38}$ exhibited the vertical orientation behavior. Therefore, we examined the LC orientation behaviors of the PORZ\# films using surface characterization techniques, viz. surface energy value measurements. Fig. 7 and Table 2 show the surface energy values of the polymer films obtained based on the static contact angles of two solvents, water and methylene iodide. The total surface energy of film was calculated using the Owens-Wendt's equation and this value is a summation of the polar and dispersion contributions. We also found that there is a critical value of polymer surface energy below which vertical LC orientation behavior is observed. The vertical LC orientation was observed with the PORZ20, PORZ40, PORZ60, PORZ80, and PORZ100 films. The total surface energies of these polymers are approximately 40.43, 37.64, 36.92, 34.28, and $33.91 \mathrm{~mJ} \mathrm{~m}^{-2}$, respectively, whereas other polymers with total surface energies larger than around $45.67 \mathrm{~mJ} \mathrm{~m}^{-2}$, such as PCMS $\left(45.67 \mathrm{~mJ} \mathrm{~m}^{-2}\right)$, did not show vertical orientation behavior. However, we could not observe the accurate and precise critical value of polymer surface energy due to the unconfirmed liquid crystal behavior and surface energy value of the other polymers having oryzanol moiety in the range of $0-20 \mathrm{~mol} \%$, as not defined in the current manuscript. We found that there is a critical value of polymer surface energy below $\left(<40.43 \mathrm{~mJ} \mathrm{~m}^{-2}\right)$ which vertical LC orientation behavior is observed in our polymer series (PORZ0, PORZ20, PORZ40, PORZ60, PORZ80, and PORZ100).

Therefore, it is very reasonable to ascribe the vertical orientation of PORZ20, PORZ40, PORZ60, PORZ80, and PORZ100 to the increased steric repulsions between LC molecules and the polymer surfaces by incorporating the nonpolar and sterically bulky oryzanol moieties into the side group of polystyrene as well as the low surface energy $\left(<40.43 \mathrm{~mJ} \mathrm{~m}^{-2}\right)$ originating from the polymers unique chemical structures of nonpolar and long carbon groups. The reliability of the LC cells fabricated with the

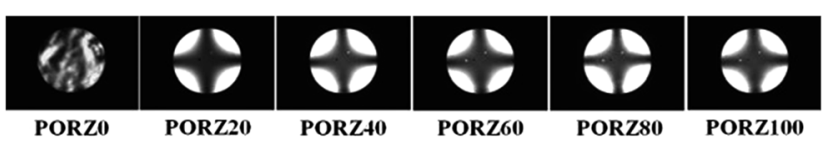

Fig. 6 Conoscopic polarized optical microscopy (POM) images of the LC cells made from PORZO (or PCMS) and PORZ20, PORZ40, PORZ60, PORZ80, and PORZ100 films. 
(a)

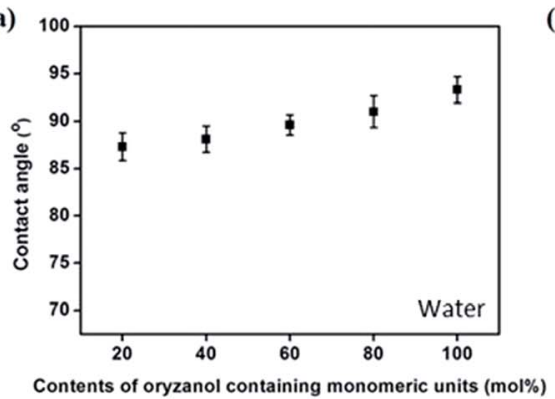

(b)

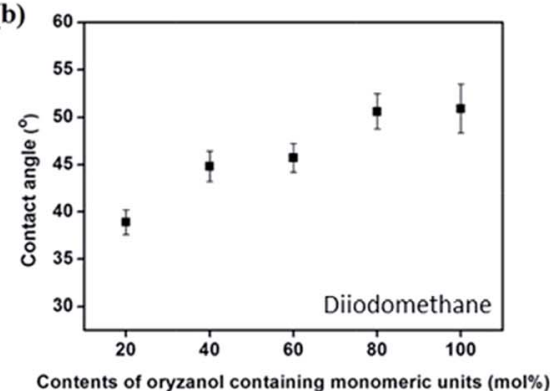

(c)

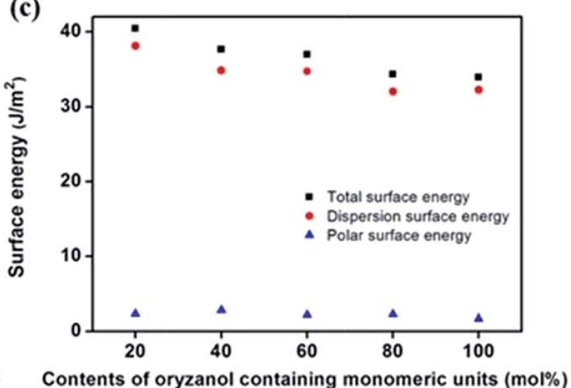

Fig. 7 (a) Water, (b) diiodomethane contact angle and (c) surface energy values of PORZ\# films according to the molar content of the $\gamma$-oryzanol moiety in the side groups.

polymer films was determined through a stability examination of the LC orientation under harsh conditions such as high temperatures and ultraviolet (UV) radiation. The thermal and UV stability of the LC cell made from the homopolymer (PORZ100) and copolymers (PORZ80, PORZ60, PORZ40, and PORZ20) was estimated from the POM image after heating for $10 \mathrm{~min}$ at 100,150 , and $200^{\circ} \mathrm{C}$ and UV irradiation at 5,10 , and $20 \mathrm{~J} \mathrm{~cm}^{-2}$, respectively. As shown in Fig. 8, no distinguishable difference of pretilt angle on PORZ100 film with vertical LC orientation can be observed, as demonstrated by the "Maltese cross" pattern in conoscopic POM images, which indicates that the vertical LC aligning ability of the PORZ100 LC cell was maintained even at the high temperature and UV energy. The total surface energies of the PORZ100 films were obtained based on the static contact angles of water and methylene iodide after heat treatment and UV irradiation also. When the temperature was increased to $200{ }^{\circ} \mathrm{C}$ and UV irradiation energy was increased to $20 \mathrm{~J} \mathrm{~cm}^{-2}$, the total surface energy of the PORZ100 film was sustained in the range of approximately 34.31 to 34.80 $\mathrm{mJ} \mathrm{m} \mathrm{m}^{-2}$. The vertical LC aligning ability of the copolymer (PORZ80, PORZ60, PORZ40, and PORZ20) LC cells was maintained at the high temperature $\left(200{ }^{\circ} \mathrm{C}\right)$ and UV energy $(20 \mathrm{~J}$ $\mathrm{cm}^{-2}$ ) (data not shown). The electro-optical (E-O) performance of the LC cell fabricated using the homopolymer (PORZ100) film was measured to determine suitability for practical LC display applications. The fabricated LC cell exhibited a voltage holding ratio (VHR) of above $99 \%$ at $25{ }^{\circ} \mathrm{C}$ and this value was maintained at $60{ }^{\circ} \mathrm{C}$. This is satisfactorily high for practical applications as the LC orientation layer in a thin film transistor (TFT) matrix-addressed display. ${ }^{1}$ The residual DC voltage (R-DC) of the LC cell was measured using the capacitance-voltage $(C-V)$ hysteresis method and was found to be very low, about $5 \mathrm{mV}$, which is even lower than that of commercial polyimides. ${ }^{1}$ The excellent thermal stability, VHR, and R-DC of the LC cell made from PORZ100 film were ascribed to the intrinsic properties of polymers with high carbon content, such as good thermal stability and low dielectric constant.

Recently, the development of plastic substrates for flexible displays has been the subject of enormous efforts. ${ }^{39}$ All of the LC cells made using the PORZ\# films on polyethylene terephthalate (PET) substrates exhibit similar LC orientation behavior compared with the LC cells fabricated with the same polymer films on glass substrates, as previously shown in Fig. 5 and 6. As shown in Fig. 9, we found that the LC cells fabricated using the PORZ20, PORZ40, PORZ60, PORZ80, and PORZ100 films on plastic PET substrates show vertical LC orientation behavior by observing the conoscopic POM images. Furthermore, the LC cell of the PET substrate showed very good vertical LC orientation, which was sustained after bending it several hundred times. Therefore, phytochemicalbased, renewably sourced PORZ\# can be considered a suitable candidate for LC orientation layers in eco-friendly flexible displays and rigid displays, including vertical alignment (VA) mode applications.

Table 2 Surface energy values and LC aligning ability of the polymers

\begin{tabular}{|c|c|c|c|c|c|c|}
\hline \multirow[b]{2}{*}{ Polymer designation } & \multicolumn{2}{|c|}{ Contact angle $^{a}\left({ }^{\circ}\right)$} & \multicolumn{3}{|c|}{ Surface energy ${ }^{b}\left(\mathrm{~mJ} \mathrm{~m}^{-2}\right)$} & \multirow[b]{2}{*}{ LC aligning ability ${ }^{c}$} \\
\hline & Water & $\begin{array}{l}\text { Methylene } \\
\text { iodide }\end{array}$ & Polar & Dispersion & Total & \\
\hline PORZ0 (or PCMS) & 71.1 & 35.2 & 8.67 & 37.00 & 45.67 & $\mathrm{X}$ \\
\hline PORZ20 & 87.3 & 38.9 & 2.33 & 38.10 & 40.43 & $\mathrm{O}$ \\
\hline PORZ40 & 88.1 & 44.8 & 2.84 & 34.80 & 37.64 & $\mathrm{O}$ \\
\hline PORZ100 & 93.3 & 50.9 & 1.69 & 32.22 & 33.91 & $\mathrm{O}$ \\
\hline
\end{tabular}

${ }^{a}$ Measured from static contact angles. ${ }^{b}$ Calculated from Owens-Wendt's equation. ${ }^{c}$ Circle $(\mathrm{O})$ and cross $(\mathrm{X})$ indicate polymer film have vertical and random planar LC aligning ability, respectively. 

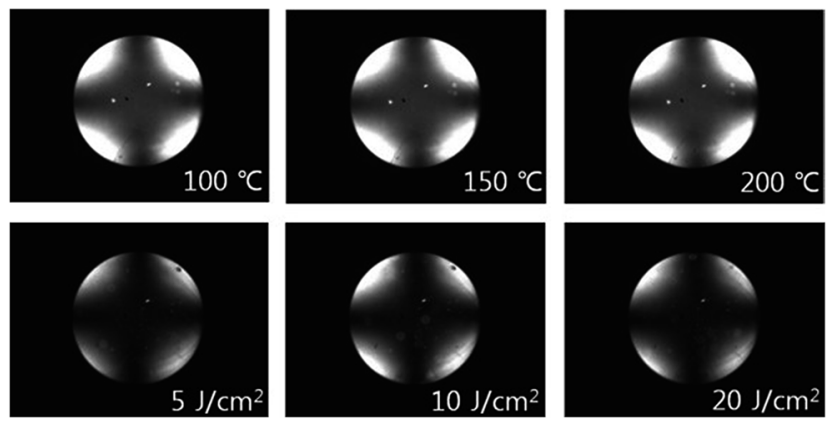

Fig. 8 Concoscopic polarized optical microscopy (POM) images of the LC cells made using PORZ100 films, after thermal treatment at 100 , 150 , and $200{ }^{\circ} \mathrm{C}$ for $10 \mathrm{~min}$ and UV treatment at 5,10 , and $20 \mathrm{~J} \mathrm{~cm}^{-2}$, respectively.

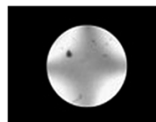

(a)

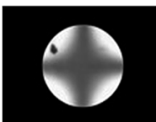

(b)

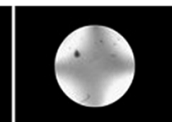

(c)

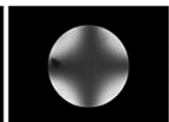

(d)

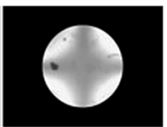

(e)
Fig. 9 Concoscopic polarized optical microscopy (POM) images of the LC cells made from PORZ\# (a) PORZ20, (b) PORZ40, (c) PORZ60, (d) PORZ80, and (e) PORZ100 films on polyethylene terephthalate (PET) substrates according to the molar content of oryzanol moiety.

\section{Conclusion}

A series of polystyrene derivatives containing plant-derived $\gamma$ oryzanol, (PORZ\#), were synthesized in order to investigate the liquid crystal (LC) orientation property of these polymer films. The LC cells incorporating films fabricated with polystyrenes with more than $20 \mathrm{~mol} \%$ of oryzanol showed vertical LC orientation. However, the LC cells made using pristine polychloromethylstyrene (PCMS) films exhibited random planar LC orientation behavior. PORZ100 polymer films exhibited good optical transparency in the visible light region $(400-700 \mathrm{~nm})$. For example, the transmittance value $(98.3 \%)$ of the PORZ100 film on glass substrate at $550 \mathrm{~nm}$ is better than that $(80.5 \%)$ of the polyimide film, the most commonly used polymer for LC orientation layers. The vertical LC orientation was ascribed to the steric repulsions between the $\mathrm{LC}$ molecule and the polymer surface due to the incorporation of a long alkyl and bulky oryzanol moiety into the side chain and was strongly correlated with the surface energy of the polymer being lower than around $40.42 \mathrm{~mJ} \mathrm{~m}^{-2}$, which is generated by the nonpolar groups. This work provides a proof-ofconcept for the design of LC orientation layers using polymers based on phytochemical-based renewably sourced oryzanol.

\section{Conflicts of interest}

There are no conflicts to declare.

\section{Acknowledgements}

Financial supports by the Dong-A University Research Fund are gratefully acknowledged.

\section{Notes and references}

1 T. Kohki, H. Masaki, K. Mitsuhiro, I. Nobuyuki, H. Ray and S. Masanori, Orientation technologies and applications of liquid crystal devices, Taylor \& Francis, New York, 2005.

2 K. Ichimura, Chem. Rev., 2000, 100, 1847.

3 J. Stöhr and M. G. Samant, J. Electron Spectrosc. Relat. Phenom., 1999, 98, 189.

4 M. Schadt, Annu. Rev. Mater. Sci., 1997, 27, 305.

5 N. Almeria and R. Paul, Chem. Rev., 2002, 102, 4139.

6 M. Ree, Macromol. Res., 2006, 14, 1.

7 M. K. Ghosh and K. L. Mittal, Polyimides: fundamentals and applications, Marcel Dekker, New York, 1996.

8 M. B. Feller, W. Chen and T. R. Shen, Phys. Rev. A: At., Mol., Opt. Phys., 1991, 43, 6778.

9 N. A. J. Van Aerle and A. J. W. Tol, Macromolecules, 1994, 27, 6520.

10 K. W. Lee, S.-H. Paek, A. Lien, C. Durning and H. Fukuro, Macromolecules, 1996, 29, 8894.

11 K. Weiss, C. Wöll, E. Höhm, B. Fiebranz, G. Forstmann, B. Peng, V. Scheumann and D. Johannsmann, Macromolecules, 1998, 31, 1930.

12 J. Stöhr, M. G. Samant, A. Cossy-Favre, J. Diaz, Y. Momoi, S. Odahara and T. Nagata, Macromolecules, 1998, 31, 1942.

13 R. Meister and B. Jerome, Macromolecules, 1999, 32, 480.

14 J. J. Ge, C. Y. Li, G. Xue, I. K. Mann, D. Zhang, S.-Y. Wang, F. W. Harris, S. Z. D. Cheng, S.-C. Hong and X. Zhuang, J. Am. Chem. Soc., 2001, 123, 5768.

15 D. Kim, M. Oh-e and Y. R. Shen, Macromolecules, 2001, 34, 9125.

16 K. E. Vaughn, M. Sousa, D. Kang and C. Rosenblatt, Appl. Phys. Lett., 2007, 90, 194102.

17 S. W. Lee, S. I. Kim, Y. H. Park, M. Ree, Y. N. Rim, H. J. Yoon, H. C. Kim and Y.-B. Kim, Mol. Cryst. Liq. Cryst. Sci. Technol., Sect. A, 2000, 349, 279.

18 Y. J. Lee, Y. W. Kim, J. D. Ha, J. M. Oh and M. H. Yi, Polym. Adv. Technol., 2007, 18, 226.

19 S. W. Lee, B. Chae, B. Lee, W. Choi, S. B. Kim and S. I. Kim, Chem. Mater., 2003, 15, 3105.

20 S. B. Lee, G. J. Shin, J. H. Chi, W.-C. Zin, J. C. Jung, S. G. Hahm, M. Ree and T. Chang, Polymer, 2006, 47, 6606.

21 H. Kang, J. S. Park, D. Kang and J.-C. Lee, Polym. Adv. Technol., 2009, 20, 878.

22 H. Kang, T.-H. Kim, D. Kang and J.-C. Lee, Macromol. Chem. Phys., 2009, 210, 926.

23 B. Dimitrios, Trends Food Sci. Technol., 2006, 17, 505.

24 L. Sunil, P. Srinivas, P. K. P. Kumar and A. G. G. Krishna, J. Food Sci. Technol., 2015, 52, 3291.

25 A. L. Branen, P. M. Dividson and B. Katz, Food Technol., 1980, 34, 42.

26 R. L. Prior, Am. J. Clin. Nutr., 2003, 78, 570 S.

27 D. Y. Ryu, K. Shin, E. Drockenmuller, C. J. Hawker and T. P. Russell, Science, 2005, 308, 236.

28 Y. Tsuda and S. Kawabata, J. Photopolym. Sci. Technol., 2014, 27, 277.

29 M. H. Suh, S. H. Yoo and H. G. Lee, Food Chem., 2007, 100, 1065. 
30 Z. Xu and J. S. Godber, J. Agric. Food Chem., 1999, 47, 2724. 31 N. Rong, L. M. Ausman and R. J. Nicolosi, Lipids, 1997, 32, 303.

32 M. Patel and S. N. Naik, J. Sci. Ind. Res., 2004, 63, 569.

33 J. Yamauchi, J. Takahara, T. Uneki and T. Ofuki, Horm. Metab. Res., 1981, 13, 185.

34 D. K. Sanghi and R. Tiwle, Int. J. Pharmacol., 2015, 5, 8.

35 D. K. Owens and R. C. Wendt, J. Appl. Polym. Sci., 1969, 13, 1741.

36 U. W. Gedde, Polymer Physics, Chapman \& Hall, London, 1st edn, 1995, ch. 5 .
37 J.-B. Lee, H.-K. Lee, J.-C. Park and Y.-B. Kim, Mol. Cryst. Liq. Cryst., 2005, 439, 161.

38 S. W. Lee, S. J. Lee, S. G. Hahm, T. J. Lee, B. Lee, B. Chae, S. B. Kim, J. C. Jung, W. C. Zin, B. H. Sohn and M. Ree, Macromolecules, 2005, 38, 4331.

39 B. A. MacDonald, K. Rollins, D. Mackerron, K. Rakos, R. Eveson, K. Hashimoto and B. Rustin, Engineered films for display technologies, in Flexible flat panel displays, John Wiley \& Sons, West Sussex, 2005, ch. 2. 